\title{
Converting Urban Waste into Energy in Kathmandu Valley: Barriers and Opportunities
}

\author{
Maria E. I. Shrestha1,2, Junun Sartohadi', M. Kholid Ridwan'3, Dyah R. Hizbaron' ${ }^{1}$ \\ ${ }^{1}$ Faculty of Geography, Gadjah Mada University, Yogyakarta, Indonesia \\ ${ }^{2}$ Kathmandu College of Management, Kathmandu, Nepal \\ ${ }^{3}$ Faculty of Engineering, Gadjah Mada University, Yogyakarta, Indonesia \\ Email: indra@kcm.edu.np
}

Received 17 April 2014; revised 12 May 2014; accepted 5 June 2014

Copyright (C) 2014 by authors and Scientific Research Publishing Inc.

This work is licensed under the Creative Commons Attribution International License (CC BY).

http://creativecommons.org/licenses/by/4.0/

c) (i) Open Access

\section{Abstract}

The population explosion, rapid urbanization rate and the increase in economic activities in Kathmandu Valley have created serious problems in various aspects, including solid waste management and energy deficiency. Despite the existence of distinct link between waste and energy, the "waste to energy" concept is still viewed as an inferior method in Nepal. The government and other concerned stakeholders pay more attention towards the development of hydropower, the major source of electricity production in Nepal. This paper intends to link between solid waste management and inadequacy in energy supply. Kathmandu Valley produces about 620 tons/day solid waste from its five municipalities. The study has shown some opportunities for Kathmandu Valley to convert its solid waste into energy. Even if only organic waste is treated, it produces energy sufficient to light more than $\mathbf{1 0 0 0}$ houses in Kathmandu Valley. The quantity of waste, its heat content, the need of additional energy supply, the support from government and service users are some openings that hopefully can contribute to resolving the problems of solid waste and energy supply in Kathmandu Valley.

\section{Keywords}

Solid Waste Management, Waste to Energy, Kathmandu Valley, Barriers, Opportunities

\section{Introduction}

Waste management has been a major problem faced by city dwellers and authorities of urban areas in many

How to cite this paper: Shrestha, M.E.I., Sartohadi, J., Ridwan, M.K. and Hizbaron, D.R. (2014) Converting Urban Waste into Energy in Kathmandu Valley: Barriers and Opportunities. Journal of Environmental Protection, 5, 772-779. 
countries. The increase in population, rapid rate of urbanization, changing life style of people and escalation of economic activities have caused serious environmental pressure, one of which is waste generation in the cities [1]. Many countries like Greece, Malaysia, China, India, Nepal, Bangladesh and many more are suffering from this problem [2].

Nepal with its urban population alone having increased from 0.238 million in 1954 to 4.53 million in 2011, is now confronting with waste management problems in most of its urban areas. However, a more serious problem is seen in Kathmandu Valley, the capital city, which accounts for approximately one third of total Nepal's urban population. The rapid urbanization in Kathmandu has made it one of the fastest growing metropolitan cities in South Asia [3]. This trend may adversely affect certain issues such as health and sanitation, drinking water supply, waste management, unplanned housing development and energy supply.

Kathmandu Valley that consists of five municipalities (Bhaktapur, Kathmandu Metropolitan City, Kirtipur, Lalitpur and Madhyapur Thimi) produces in average 620 tons of solid waste per day [4]. This huge amount of waste has been creating problems in disposal as well as treatment. Serious environmental problems have affected the life of people in Kathmandu Valley. While people are facing the problems, the solid waste management in Kathmandu Valley remains a big question mark. Kathmandu Metropolitan City authority has not properly organized the solid waste disposal. The stockpiles of solid waste can be seen everywhere, at the side of the road, along the river banks, near vegetable markets and many other corners in the city.

On the other side, as mentioned earlier, the population growth has also affected the supply of energy (electricity and petroleum products) in Kathmandu Valley. This paper intends to draw a link between two major problems arising in Kathmandu Valley: the solid waste management and inadequate supply of energy to the city occupants.

\section{Literature Review}

This study uses mainly a literature survey and secondary data for analysis and discussion. Asian Development Banks reports, Central Bureau of Statistics, Nepal Oil Corporation, Nepal Electricity Authority are some of the sources for obtaining the data to be used in this study.

\subsection{Solid Waste Management (SWM) System in Urban Areas}

Solid waste management has been a major issue in many developing countries. In Greece, until late 1980s, solid waste was buried in landfill sites and frequently also seen being thrown in open dumping sites. The lack of systematic facilities, coordination and governance of the concerned institutions has created serious problems in the solid waste disposal [5]. However, later, the legislation and environmental planning of Greece has set the target to implement internal SWM, followed by the ongoing reduction of biodegradable solid waste which is presently steering to landfilling, increasing recycle activities and also the closure of open dumping sites [5]. One of the recently proposed ways of waste management is to recover the energy from the waste through high temperature thermal treatment, as waste contains significant amount of biodegradable matters, that is expected be used as renewable energy source [6].

India is an example of a fast growing country. Rapid growth of industrialization, population and urbanization has caused huge amount of municipal solid waste that lead to environmental degradation [7]. Unfortunately, most of the cities there are not able to cope up with environmental pressure due to lack of facilities. With waste generation per capita of $0.5 \mathrm{~kg} /$ day, India is facing a major challenge in municipality solid waste management [2]. Sharholy et al. (2008) has conducted rigorous review on solid waste management in Indian context. Mindsets are changing with the progress of development and education. The price hike in petroleum products and other power have enforced the concerned institutions and investors to make energy recovery projects from waste become more practical (Sharholy cited in [8]).

In response to Kyoto Protocol and agreement in Marrakech, Korea has been giving serious attention on $\mathrm{CO}_{2}$ emission reduction. The development of renewable energy is considered as one way to reduce $\mathrm{CO}_{2}$ emission and socio-economic cost due to environmental pressure. As one of the possible sources of energy alternative, the government has been promoting the expansion of landfill gas for electricity generation. Shin et al. (2005) had conducted economic and environmental analysis to see the prospect of landfill gas to generate electricity, under various scenarios of technology. The result showed that electricity generation from waste using steam turbine was the most economical way. However, there are still uncertainties in utilizing landfill gas and the introduction of it 
to energy market. The technology, economy and regulations are few to take into account in promoting waste to energy concept in Korea [9].

Indonesia is the countries in fourth position in the world in its population (UNFPA World Population 2012). Gunamantha has perceived that solid waste management solution is not a straight forward problem. The collection and disposal are not the final answer. Different types of methods are available, but the characteristic of waste which is not homogeneous, has created other hindrances. The life cycle assessment on various ways to recover the energy from solid waste in Yogyakarta province has been conducted to encounter questions such as: anaerobic digestion or landfill, thermal conversion or landfill, loss or benefit to the environment [10]. The study showed that direct gasification was supposed to be the safest method in energy recovery from solid waste. Life cycle assessment was considered the appropriate technique to evaluate diverse waste treatment methods in relation to their environmental impact.

\subsection{Waste to Energy Concept}

Waste to energy is a process of converting waste into gas or electricity. The sources of waste can be from residence, industries, commerce and institutions (offices). The term "waste" implies a non-usable by product of a production process. The first process noticed in the history is the incineration built in Denmark in 1903 [11]. As the energy consumption keeps on increasing, the concept to transform waste (solid waste, to be more specific) into energy has become one of the core issues in promoting an alternative source of energy. The concern on minimizing environmental pressure and the need of energy for living have created a strong linkage between waste and energy [11].

So far the solid waste is concerned, recycling and reusing are the most preferred methods in most of waste management program. However, converting waste to energy is viewed as a key aspect in solid waste management. In the previous years, burning solid waste was a method to shrink the volume of solid waste and to reduce its harmful effect to human health. Today, waste incineration is combined with the extraction of energy [12].

Solid waste can be converted into energy through various conversion processes. The most common techniques to convert waste into energy have been identified as thermal conversion, biochemical conversion and landfilling [2].

Thermal conversion techniques include incineration (combustion), pyrolysis, gasification and refuse derived fuel (RDF). The combustion involves burning organic waste and other components like textile and plastic. The heat resulted from this process is converted into electricity. The emission of toxic gases as a side effect of these process is the main drawback of thermal conversion.

Considered as more environmentally friendly process, biochemical conversion comes as an alternative. Composting, vermicomposting and anaerobic digestion are those under biochemical conversion process. Thermal conversion in this method covers trans-esterification and other processes to convert plants and bio oil into biodiesel (Annepu cited in [2]); [7].

Landfilling is the most common method used in developing and least developed countries. The simple landfill is a technique to dispose solid waste in an open space. This method is easy but is not environmentally sound. The waste is usually wide-opened and prone to open burning. Unfortunately, most of landfill sites are not (or minimal) equipped with the facility to remove dust [13]. With low effectiveness in controlling pollution, this method is not the one that can be taken as an appropriate option.

\section{The Energy Crisis and the Status of Waste to Energy Concept in Nepal}

Nepal is currently experiencing serious energy crisis. It is now becoming a crucial constriction for the development of social-economy of the country. Despite its richness in hydropower potential, Nepal is currently making the maximum of only $1 \%$ of its ability to produce $83,000 \mathrm{MW}$ of hydropower.

According to the statement of the Renewable Energy for Rural Livelihood (RERL), there is significant shortage in capacity as well as in energy supply compared to the public demands. In order to overcome this problem, the Government of Nepal has established High Level Taskforces to chart out plans for generating 10,000 MW hydropower in 10 years, and 25,000 MW hydropower in 20 years. However, the speed towards developing hydropower has not yet accelerated. The impact of this is that now people of Nepal are facing acute load shedding problem and this is even increasing, despite a potential opportunity for Nepal to become a power exporter to India, as mentioned in Energy Sector Synopsis Report, 2010, by WECS [14]. Likewise, such a thing happens to 
petroleum product. With no deposit of coal and fossil fuel, Nepal highly depends on the supply from India and has to suffer loss of several products due to subsidy policy.

In the area of renewable energy, Alternative Energy Promotion Center (AEPC), a national pivotal government organization for promoting renewable and alternative energy technologies in Nepal, has been painstakingly conducting numbers of researches with main focus on maximizing the service delivery in the use of renewable energy resources and technologies in the rural areas and providing opportunity to low-income rural households to use renewable energy technology. However, despite various renewable energy sources that need to be explored further, most of stakeholders pay more attention towards hydropower development, which is still in low pace to step ahead to fulfill the electricity demand. Renewable energy shall be considered as immediate solution to energy crisis that has been a permanent feature in the life of people, especially in urban areas. Solar, biomass and microhydro are some of those to be explored to resolve the energy crisis in Nepal.

\section{The Barriers}

Waste to energy is still viewed as an inferior concept in Nepal. The attention towards producing energy is focused more on hydropower due its abundant potential to produce electricity. This view, somehow, halt the move to promote converting waste into energy. Despite the serious problems of piled-up solid waste in Kathmandu Valley, the authority has not taken any significant attempts to solve solid waste management in the valley.

As studied by JICA (Japan International Cooperation Agency), the common issues in solid waste management in Kathmandu Valley are collection and transportation, solid waste minimization, final disposal, social aspects, managerial aspects and financial aspects [15].

\subsection{The Collection Technique}

Collection time is one factor that affects the effectiveness of collection and transportation of solid waste into dumping sites. Day time collection is more convenient for the workers, but at the same time it creates problem in traffic and pollution due to improper way of transporting the waste (waste drops as well as unpleasant smell and scene). The collection efficiency also has not been up to the mark. Kathmandu Metropolitan City has the highest collection efficiency of $86.9 \%$, followed by Bhaktapur with $86.5 \%$, while the efficiency in Kirtipur is only $35.3 \%$ [4]. Night time or early morning collection could be a challenge for the authority in order to improve the collection efficiency.

\subsection{Waste Separation}

Lack of practice in waste separation is another issue. Most of domestic solid waste is found not well segregated. Separation of organic waste from other components is required when anaerobic digestion system is used to convert waste into energy. Incineration could be another option that does not required separation of organic waste as it can include plastic and textiles to be incinerated to produce heat. However, this technique has serious environmental impacts on air pollution. Emission of toxic gasses is the major disadvantage of this technique. The study on air pollution in Kathmandu Valley revealed that CO (carbon monoxide) emission had reached to 178,570 $\mu \mathrm{g} / \mathrm{m}^{3}$, almost six times higher than the standard published by WHO which is $30,000 \mu \mathrm{g} / \mathrm{m}^{3}$ [16].

\subsection{Dumping Site}

Open dumping is the major disposal method in Nepal. Among five municipalities, Kathmandu Metropolitan City has produced the highest amount of solid waste, followed by Lalitpur Sub Metropolitan City (Figure 1). The two cities and Bhaktapur have been disposing their solid waste in Sisdole landfill site since 2005. With capacity of holding only 275,000 tons of waste, Sisdole will not be able to cope with the increase of solid waste generation (http://www.gorkhapatra.org.np/detail.php?article_id=9936\&cat_id=4). This problem has forced the authority to construct a new one in Bancharedanda and to shut down the Sisdolesite in the near future. Bancharedanda is supposed to be the largest landfill site in Nepal. Nevertheless, many municipalities have been facing the problem of waiting the government decision for the approval of land acquisition [4]. Bureaucracy has created problem in the availability of space for solid waste final disposal.

In addition to this problem, it may be difficult to find land available for dumping site in the future as population is keep on increasing. Ecologically, it is not wise to continue with landfilling as a technique for solid waste 


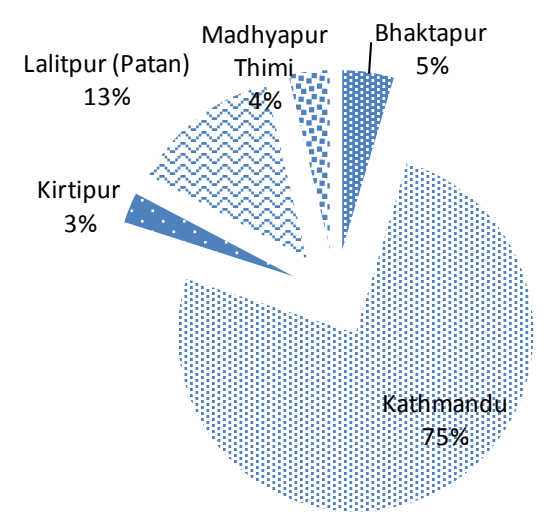

Figure 1. Solid waste generation in Kathmandu Valley.

management for long term. Fear of failure of the landfill's liner, the pollutant would reach the groundwater system. Consequently, groundwater will carry the pollutant into water body nearby, spreading hazardous toxic effect. The effect can stay up to 25 years after the closure of the landfill site [17].

Addressing those issues requires a joined-hand between the government, citizens and other related institutions (national and international agencies and private sectors). Several researches and studies on waste management have been conducted by some of them. However, many have not investigated the introduction of waste to energy concept in its study. It is high time to explore other techniques that are more environmentally safe and have potential contribution to solving energy crisis in Nepal, specifically Kathmandu Valley.

\section{The Opportunities}

Recalling the impacts of urbanization and scaling up of economic activities in Kathmandu Valley, it is necessary to find a way out to handle them. Energy supply and waste management are becoming problematic issues in the Valley. Even though hydropower in Nepal has huge potential to produce electricity, it does not provide any immediate solution. Waste to energy concept, how small it is, can contribute in supplying energy to the people of Kathmandu Valley. Some prospects on converting urban waste into energy are presented in this section.

\subsection{The Energy Content of Solid Waste in Kathmandu Valley}

Solid waste consists of various components. Assessing the potential energy from solid waste is not simple as different materials have different calorific values.It is necessary to know the composition of solid waste to obtain its heat content. The moisture content is also important factor to determine how much heat can be extracted from solid waste. Figure 2 and Figure 3 shows the composition of solid waste from various sectors in Kathmandu Valley.

Determining the heat content of solid waste is done by using the data of heat values of various material consisted in municipal solid waste. Table 1 exhibits the heat value of different type of material on dry basis. Heat content is calculated using the following formula:

$$
\text { Heat content }(\mathrm{HC})=\mathrm{f}_{\mathrm{i}} * \mathrm{HV}_{\mathrm{i}}
$$

where $f_{i}=$ the fraction of component $i$

$\mathrm{HV}_{\mathrm{i}}=$ Heat Value of component $i$

In a simple way, the heat content of solid waste of Kathmandu Valley is calculated as follows:

$$
\begin{aligned}
\mathrm{HC} & =0.45 * 7.6+0.16 * 22.6+0.25 * 6.7+0.02 * 0.1+0.01 * 0.7+0.02 * 13.8+0.01 * 20.65 \\
& =9.2 \text { million Btu }
\end{aligned}
$$

The analysis shows that each ton of solid waste in Kathmandu Valley has potential to produce 9.2 million Btu. It means that every day, a total of 2.7 MW energy theoretically can be generated from solid waste in Kathmandu Valley. Even if only organic waste is incinerated (as other components can be recycled or reused), it will produce about 3.42 million Btu (1.3 MW), which is enough to light approximately of 1000 households. It is not high amount, but not too less to be neglected. 


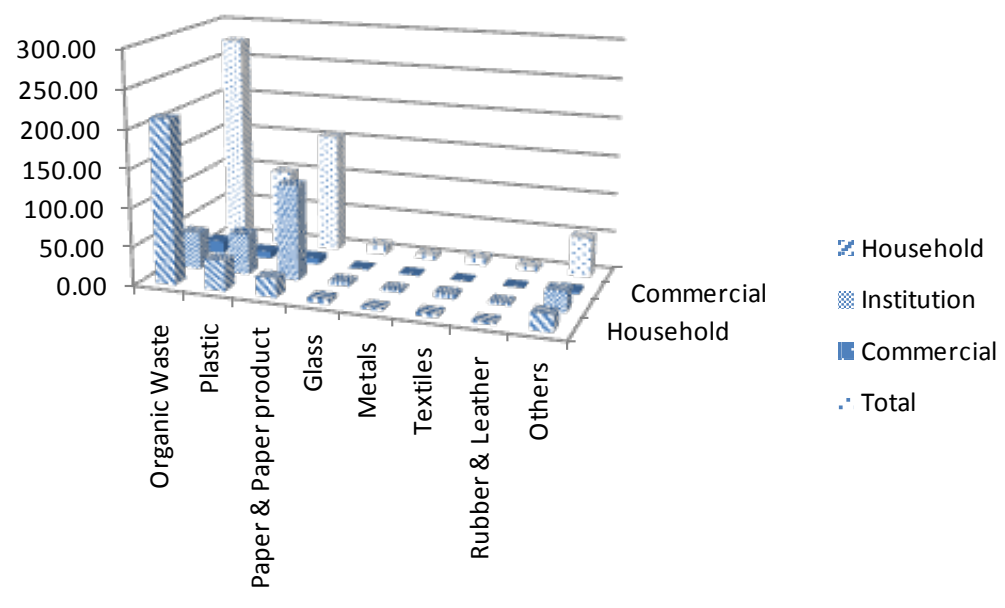

Figure 2. Solid waste composition from various sectors in Kathmandu Valley.

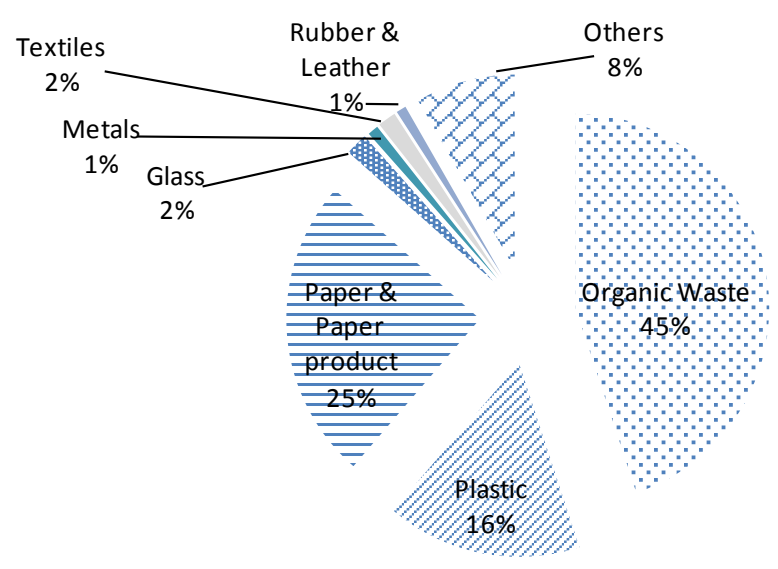

Figure 3. Kathmandu Valley solid waste composition.

Table 1. Average heat value of possible component in solid waste.

\begin{tabular}{cc}
\hline Component & Heat Value (Million Btu/ton) \\
\hline Plastic & 22.6 \\
Rubber & 26.9 \\
Leather & 14.4 \\
Textiles & 13.8 \\
Glass & 0.1 \\
Organic Waste & 7.6 \\
Paper & 6.7 \\
Metal & 0.7 \\
\hline (Source: http://www.epa.gov/msw/msw99.htm)
\end{tabular}

\subsection{Government Policy and Support}

The implementation of waste to energy concept requires relatively high initial investment. It needs full support from government. The Government of Nepal has taken foremost step with the ratification of Solid Waste Management Act in 2011, though it has not been successfully turned into actions. Now the government is in the process of devising new policy in solid waste management under which municipalities are encouraged to developed strategy to improve the carrying out of solid waste management in their respective region [4]. 
Moreover, the Alternative Energy and Promotion Center under the Ministry of Science, Technology and Environment, has come up with a Waste to Energy Project called Scaling-Up Renewable Energy Program (SREP) and has been soliciting proposals from interested parties across Nepal. The program intends to commercialize energy recovery from urban waste of various sectors. However, the environmental impact need to be taken into account and for that the government has prepared Environmental Management Framework that will work as a guideline to identify, assess, mitigate and monitor potential environmental impacts/risks of projects and activities targeted under the SREP [18]. This move shows the initiative and awareness of the government of Nepal on the importance of managing solid waste and the production of clean energy. It will motivate private sector as well to take part in providing service to manage solid waste.

\subsection{Cost Recovery and Social Benefits}

The Solid Waste Management Act gives the direction to local bodies (municipalities) to impose the service charge to perform the service. From a survey, it was found that $82 \%$ of respondents would be willing to pay given the condition that the service level is improved [4]. Although the fee collection has not been effective, willingness to pay shows that people are prepared for a progress. Most of municipalities in Nepal allocate very small amount of budget for solid waste management. The expenditure usually cannot be recovered from that budget. Financial contribution from service users will surely make the service sustains in the future. Increasing the fee collection coverage shall be the first effort. Gradually, the strategy can be carried on to increase the fee per household.

Moreover, the benefit of implementing waste to energy should not be viewed from financial aspect alone. Converting waste into energy will reduce the air and water pollution level, provide healthier environment and producing substantial energy for the people. These intangible benefits are often overlooked.

\section{Conclusions and Recommendation}

Solid waste management is a multi-aspects issue. In case of Kathmandu Valley, the issue is still at the basic level. There are many challenges to be faced by government, public, private sector and other stakeholders. The technique, technology, people awareness, management and financial issues are some to be encountered. However, there are many considerable opportunities to be noted. The potential of solid waste to be converted into energy, the backing from government and the interest from private sector to get involved would be the forethought to move ahead.

Some recommendations would be on the government's side to set strong policy on solid waste management and to provide with clear guideline on the technique to collect and transport the waste. It can start with more hygienic landfill site. Open dumping needs to be stopped and it shall be replaced with sanitary landfill. Anaerobic digestion is supposed to be the most economical technology to convert solid waste energy. Eventually, the government will need to support private sectors in acquiring technology to convert solid waste into gas or electricity to fulfill the demand on energy.

\section{Acknowledgements}

The data for analysis is extracted from Asian Development Bank Report on the study of Solid Waste Management in Nepal: Current Status and Policy Recommendation.

\section{References}

[1] Minghua, Z., Xiumin, F., Rovetta, A., Qichang, H., Vicentini, F., Bingkai, L., Giusti, A. and Yi, L. (2009) Municipal Solid Waste Management in Pudong New Area, China. Waste Management, 29, 1227-1233.

[2] Kalyani, K.A. and Pandey, K.K. (2014) Waste to Energy Status in India: A Short Review. Renewable and Sustainable Energy Reviews, 31, 113-120. http://dx.doi.org/10.1016/j.rser.2013.11.020

[3] Pant, B. (2012) Issues of Urban Governance in Nepal: With Special Reference to Kathmandu.

[4] ADB (2013) Solid Waste Management in Nepal.

[5] Boemi, S., Papadopoulos, A., Karagiannidis, A. and Kontogianni, S. (2010) Barriers on the Propagation of Renewable Energy Sources and Sustainable Solid Waste Management Practices in Greece. Waste Management and Research, 28, 967-976. http://dx.doi.org/10.1177/0734242X10375867 
[6] Rentizelas, A.A., Tolis, A.I. and Tatsiopoulos, I.P. (2014) Combined Municipal Solid Waste and Biomass System Optimization for District Energy Applications. Waste Management, 34, 36-48. http://dx.doi.org/10.1016/j.wasman.2013.09.026

[7] Singh, R.P., Tyagi, V.V., Allen, T., Ibrahim, M.H. and Kothari, R. (2011) An Overview for Exploring the Possibilities of Energy Generation from Municipal Solid Waste (MSW) in Indian Scenario. Renewable and Sustainable Energy Reviews, 15, 4797-4808. http://dx.doi.org/10.1016/j.rser.2011.07.071

[8] Kumar, K.N. and Goel, S. (2009) Characterization of Municipal Solid Waste (MSW) and a Proposed Management Plan for Kharagpur, West Bengal, India. Resources, Conservation and Recycling, 53, 166-174. http://dx.doi.org/10.1016/j.resconrec.2008.11.004

[9] Shin, H.-C., Park, J.-W., Kim, H.-S. and Shin, E.-S. (2005) Environmental and Economic Assessment of Landfill Gas Electricity Generation in Korea Using LEAP Model. Energy Policy, 33, 1261-1270. http://dx.doi.org/10.1016/j.enpol.2003.12.002

[10] Gunamantha, M. (2012) Life Cycle Assessment of Municipal Solid Waste Treatment to Energy Options: Case Study of Kartamantul Region, Yogyakarta. Renewable Energy, 41, 277-284. http://dx.doi.org/10.1016/j.renene.2011.11.008

[11] Habib, K., Schmidt, J.H. and Christensen, P. (2013) A Historical Perspective of Global Warming Potential from Municipal Solid Waste Management. Waste Management, 33, 1926-1933. http://dx.doi.org/10.1016/j.wasman.2013.04.016

[12] Bosmans, A., Vanderreydt, I., Geysen, D. and Helsen, L. (2013) The Crucial Role of Waste-to-Energy Technologies in Enhanced Landfill Mining: A Technology Review. Journal of Cleaner Production, 55, 10-23. http://dx.doi.org/10.1016/j.jclepro.2012.05.032

[13] Hui, Y., Li'ao, W., Fenwei, S. and Gang, H. (2006) Urban Solid Waste Management in Chongqing: Challenges and Opportunities. Waste Management, 26, 1052-1062. http://dx.doi.org/10.1016/j.wasman.2005.09.005

[14] WECS (2010) Energy Sector Synopsis Report 2010. Kathmandu.

[15] JICA (2005) The Study on the Solid Waste Management for the Kathmandu Valley. Final Report Volume I: Executive Summary.

[16] Shrestha, R.M. and Malla, S. (2013) Air Pollution from Energy Use in a Developing Country City: The Case of Kathmandu, Nepal.

[17] Wichmann, H., Kolb, M., Jopke, P., Schmidt, C., Alawi, M. and Bahadir, M. (2006) Assessment of the Environmental Impact of Landfill Sites with Open Combustion Located in Arid Regions by Combined Chemical and Ecotoxicological Studies. Chemosphere, 65, 1778-1783. http://dx.doi.org/10.1016/j.chemosphere.2006.04.058

[18] AEPC (2013) Scaling up Renewable Energy Program Waste to Energy Project Nepal Social Management Framework (SMF) Alternative Energy Promotion Centre (AEPC). Ministry of Science, Technology and Environment, Kathmandu. 
Scientific Research Publishing (SCIRP) is one of the largest Open Access journal publishers. It is currently publishing more than 200 open access, online, peer-reviewed journals covering a wide range of academic disciplines. SCIRP serves the worldwide academic communities and contributes to the progress and application of science with its publication.

Other selected journals from SCIRP are listed as below. Submit your manuscript to us via either submit@scirp.org or Online Submission Portal.
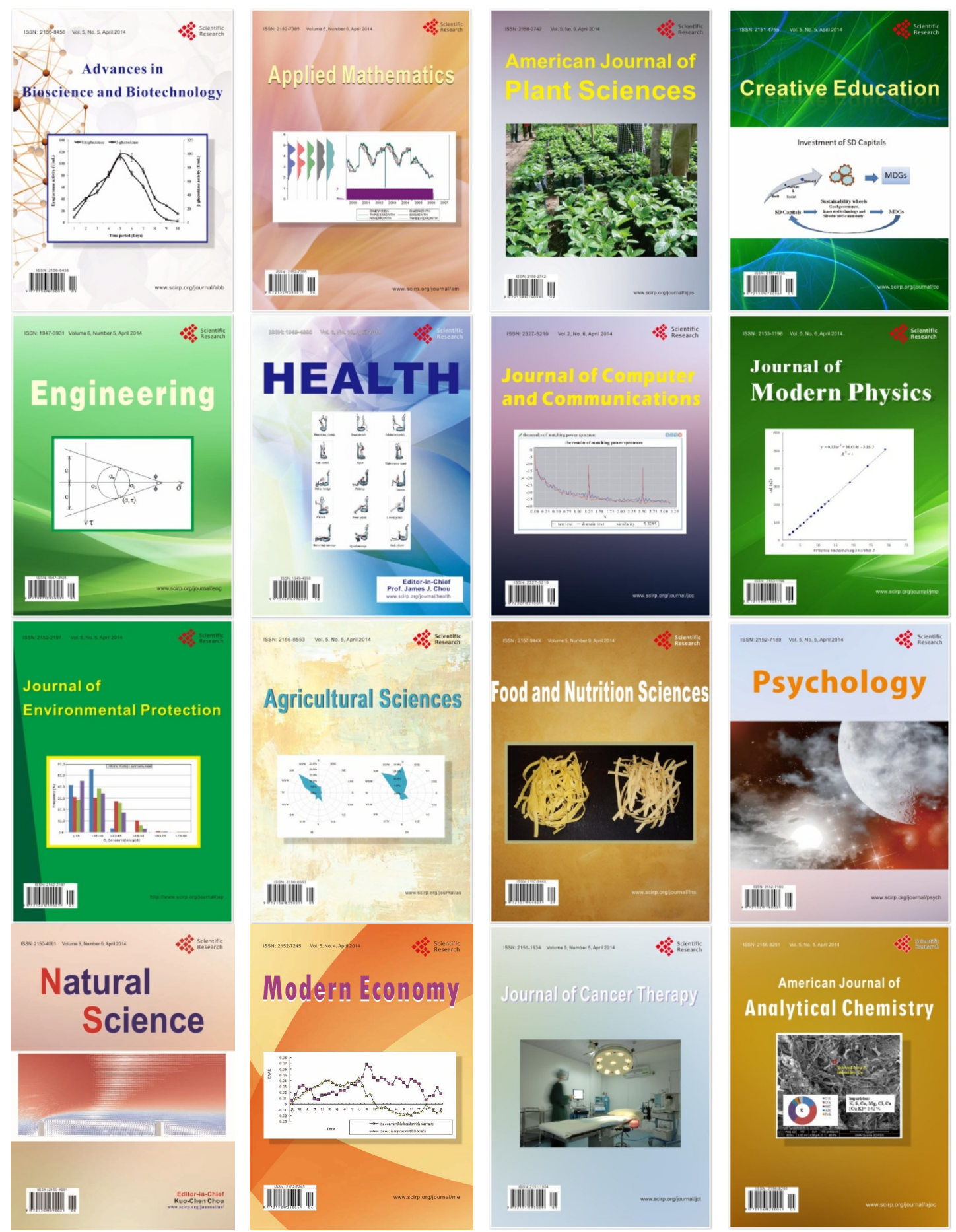